\title{
Os Futuros Contingentes em De Interpretatione 9 - uma discussão
}

\author{
Apresentação
}

No início dos anos 2010, professores e pesquisadores do Programa de PósGraduação em Lógica e Metafísica da Universidade Federal do Rio de Janeiro se reuniram regularmente para leitura e discussão do De Interpretatione de Aristóteles; destas reuniões participaram também alguns professores da Universidade de São Paulo. As discussões tornaram-se intensas, como era de se esperar, no momento da leitura do capítulo nono, dedicado ao argumento determinista e sua recusa por parte de Aristóteles. Dois colóquios foram organizados no Rio de Janeiro sobre este tema: o colóquio $A$ Questão dos Futuros Contingentes, organizado pelo próprio PPGLM, em abril de 2014, e o seminário Da Interpretação, organizado, no ano seguinte, em abril de 2015, pelo Núcleo de Estudos de Filosofia Antiga da Pontifícia Universidade Católica do Rio de Janeiro. As discussões não arrefeceram, muito pelo contrário, e o PPGLM voltou a ser palco de discussões regulares sobre modalidades e o De Interpretatione nestes últimos dois anos. Os artigos publicados aqui foram lidos nos colóquios mencionados acima ou foram escritos em direta relação com as discussões ocorridas neles. Inicialmente, estava prevista a publicação de um livro que conteria, além destes artigos, também a tradução para o português do De Interpretatione 9, realizada com muita destreza por Ricardo Santos (Imprensa Nacional - Casa da Moeda, 2016), bem como versões inéditas para o português do comentário de Amônio, do segundo comentário de Boécio, assim como de outros textos que são peças importantes ou úteis para nossa informação sobre esta célebre disputa (como o capítulo 26 do Didaskalikos de Alcinoo e o Problema I 4 atribuído a Alexandre de Afrodísia). Por diferentes motivos, o projeto do livro teve de ser postergado; publicamos, por ora, os artigos, em uma primeira versão, pois serão revistos para a edição em livro - a qual, esperamos, ocorrerá em um futuro contingente, mas não muito distante.

\section{O Editor}

